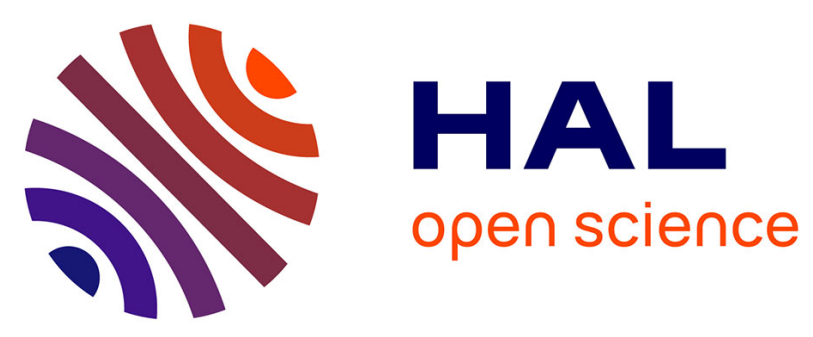

\title{
Ornithine transcarbamylase (OTC) deficiency based on a hemizygous p.R277W mutation causing life-threatening hyperammonemic crisis during treatment for Hodgkin's lymphoma
}

Ellen Ritter, Ralf A. Husain, Katrin Hinderhofer, Tino Prell, Hans-Jörg

Fricke, Sebastian Scholl, Andreas Hochhaus, Paul La Rosée

\section{To cite this version:}

Ellen Ritter, Ralf A. Husain, Katrin Hinderhofer, Tino Prell, Hans-Jörg Fricke, et al.. Ornithine transcarbamylase (OTC) deficiency based on a hemizygous p.R277W mutation causing life-threatening hyperammonemic crisis during treatment for Hodgkin's lymphoma. Annals of Hematology, 2010, 90 (7), pp.857-859. 10.1007/s00277-010-1106-y . hal-00615407

\section{HAL Id: hal-00615407 https://hal.science/hal-00615407}

Submitted on 19 Aug 2011

HAL is a multi-disciplinary open access archive for the deposit and dissemination of scientific research documents, whether they are published or not. The documents may come from teaching and research institutions in France or abroad, or from public or private research centers.
L'archive ouverte pluridisciplinaire HAL, est destinée au dépôt et à la diffusion de documents scientifiques de niveau recherche, publiés ou non, émanant des établissements d'enseignement et de recherche français ou étrangers, des laboratoires publics ou privés. 


\section{Ornithine transcarbamylase (OTC) deficiency based on a hemizygous p.R277W mutation causing life threatening hyperammonemic crisis during treatment for Hodgkin's lymphoma}

Ellen Ritter ${ }^{1}$, Ralf A. Husain ${ }^{2}$, Katrin Hinderhofer ${ }^{4}$, Tino Prell ${ }^{3}$, Hans-Jörg Fricke ${ }^{1}$, Sebastian Scholl ${ }^{1}$, Andreas Hochhaus ${ }^{1}$, and Paul La Rosée ${ }^{1 *}$

${ }^{1}$ Abteilung Hämatologie und Onkologie, Klinik für Innere Medizin II

${ }^{2}$ Klinik für Kinder- und Jugendmedizin

${ }^{3}$ Hans-Berger-Klinik für Neurologie Universitätsklinikum Jena

${ }^{4}$ Institut für Humangenetik, Universität Heidelberg

Running title: Adult-onset OTC deficiency

Number of words in the paper (excluding references and legend) -673 Number of figures -1

Keywords: ornithine transcarbamylase deficiency, hyperammonemia, corticosteroids, Hodgkin's lymphoma

* To whom correspondence should be sent at the following address:

PD. Dr. med. P. La Rosée

Abteilung Hämatologie und Onkologie, Klinik für Innere Medizin II, Universitätsklinikum Jena, 07747 Jena, Germany

Phone: +49 (0)3641 9324233

Fax: +49 (0)3641932 4202

E-mail: paul.larosee@med.uni-jena.de 


\section{Dear Editor,}

We report on a rare case of ornithine transcarbamylase (OTC) deficiency as origin for life threatening hyperammonemia in a young adult male patient with Hodgkin's lymphoma.

\section{Clinical case report}

The reported patient was diagnosed with mediastinal Hodgkin's lymphoma (Ann Arbor stage IA) at the age of 23 years in November 2008. He underwent initial remission induction with chemotherapy (doxorubicin, bleomycin, vinblastine, dacarbazine) and involved field irradiation. In April 2009, early relapse (stage IIA) caused upper airway obstruction. Immediate treatment with intravenous prednisolone (continued with methylprednisolone p.o.) and irradiation was initiated. Four weeks later the patient presented with reduced vigilance finally progressing to coma. Blood testing revealed markedly elevated plasma ammonia levels $(>400 \mu \mathrm{mol} / \mathrm{l}$, reference range [RR] 16-48 $\mu \mathrm{mol} / /$; Fig. 1); bilirubin and aminotransferases were marginally elevated. Electroencephalography displayed a moderately severe general alteration suggestive of metabolic encephalopathy. Cranial magnetic resonance imaging (MRI) showed slight cerebral edema and bilateral subcortical FLAIR hyperintensities in the precentral region with patchy distribution. Cerebrospinal fluid analysis, liver MRI and histology, drug and medication screening as well as microbiological investigations were negative. Corticosteroids were discontinued and the patient recovered completely without extensive anti-hyperammonemic therapy. In June 2009, chemotherapeutic treatment of relapse was initiated with dexamethasone, cytarabine and cisplatin (DHAP), and switched to the Dexa-BEAM regimen (dexamethasone, 
carmustine, etoposide, cytarabine, melphalan) due to refractory disease. Twelve days after the onset of Dexa-BEAM the patient again presented with nausea, vomiting, and progressive loss of vigilance. He was transferred to the intensive care unit for transient mechanic ventilation. Blood testing revealed severe hyperammonemia (Fig. 1), reduced citrulline (13 $\mu \mathrm{mol} / \mathrm{l}, \mathrm{RR} 19-55 \mu \mathrm{mol} / \mathrm{l})$ and slightly elevated alanine levels (622 $\mu \mathrm{mol} / \mathrm{l}, \mathrm{RR} 241-597 \mu \mathrm{mol} / \mathrm{l})$ pointing to a possible block of ureagenesis at the level of or proximal to OTC. Other plasma amino acids (including arginine and glutamine) and urinary orotic acid were in the reference range. Blood glucose, lactate, carnitine, acylcarnitines and urinary organic acids were normal. Accordingly, severe hepatic failure, organoacidurias and disorders of fatty acid oxidation appeared unlikely. Molecular analysis revealed a point mutation in the OTC gene leading to an exchange of arginine by tryptophan at position 277 (p.R277W mutation). Encephalopathy resolved within two days and further chemotherapy was continued without dexamethasone. In November 2009 the patient received autologous peripheral blood stem cell transplantation after a single dose of prednisolone (100 mg i.v.). Treatment was well tolerated and hyperammonemic encephalopathy did not re-occur. In January 2010, however, the patient died from infectious complications.

Catalyzing the carbamylation of citrulline, mitochondrial OTC is crucially involved in ureagenesis and ammonia elimination. Currently, more than 300 mutations compromising enzyme activity are known [1]. OTC deficiency is an X-linked disorder [2] that represents the most frequent inherited urea cycle defect. Hemizygous males with complete OTC deficiency display severe hyperammonemia within the first week(s) of life. Although males and heterozygous females with subtotal defects 
frequently present later, adult-onset OTC deficiency is rare [3-5] and found mostly in females with unfavorable lyonization.

Several environmental factors have been implicated as potential triggers of late-onset OTC deficiency. These include valproate [6], gastrointestinal bleeding [7], parenteral nutrition [8] and possibly corticosteroids [5,9]. In the present case hyperammonemic encephalopathy and steroid administration showed correlation, and, in addition, a corticosteroid-dose dependence of the clinical manifestations was evident (Fig. 1). Notably, chemotherapy without corticosteroids did provoke neither hyperammonemia nor encephalopathy. This suggests that both episodes of hyperammonemic encephalopathy resulted from a steroid-induced excessive protein catabolism on the background of a pre-existent reduction in the capacity of ammonia clearance. The latter was found to result from a specific mutation in the ornithine transcarbamylase (OTC) gene (p.R277W) previously shown to be associated with late disease onset [10]. Further genetic testing revealed the same mutation in the patient's mother and his thirteen-year-old brother both of whom were asymptomatic.

In conclusion, the reported case illustrates that late-onset OTC deficiency should be considered in hyperammonemic patients treated with steroids. Genotyping is essential for diagnosis, as our patient did not show elevated orotic acid commonly assumed to be central for the diagnosis of OTC deficiency. 


\section{References}

1. Yamaguchi S, Brailey LL, Morizono H, Bale AE, Tuchman M (2006) Mutations and polymorphisms in the human ornithine transcarbamylase (otc) gene. Hum Mutat 27 (7):626-632

2. Lindgren V, de Martinville B, Horwich AL, Rosenberg LE, Francke U (1984) Human ornithine transcarbamylase locus mapped to band xp21.1 near the duchenne muscular dystrophy locus. Science 226 (4675):698-700

3. Rohininath T, Costello DJ, Lynch T, Monavari A, Tuchman M, Treacy EP (2004) Fatal presentation of ornithine transcarbamylase deficiency in a 62-year-old man and family studies. J Inherit Metab Dis 27 (2):285-288

4. Harada E, Nishiyori A, Tokunaga $Y$, Watanabe $Y$, Kuriya N, Kumashiro R, Kuno $T$, Kuromaru R, Hirose S, Ichikawa K, Yoshino M (2006) Late-onset ornithine transcarbamylase deficiency in male patients: Prognostic factors and characteristics of plasma amino acid profile. Pediatr Int 48 (2):105-111

5. Atiq M, Holt AF, Safdar K, Weber F, Ravinuthala R, Jonas ME, Neff GW (2008) Adult onset urea cycle disorder in a patient with presumed hepatic encephalopathy. $J$ Clin Gastroenterol 42 (2):213-214

6. Thakur V, Rupar CA, Ramsay DA, Singh R, Fraser DD (2006) Fatal cerebral edema from late-onset ornithine transcarbamylase deficiency in a juvenile male patient receiving valproic acid. Pediatr Crit Care Med 7 (3):273-276

7. Trivedi M, Zafar S, Spalding MJ, Jonnalagadda S (2001) Ornithine transcarbamylase deficiency unmasked because of gastrointestinal bleeding. J Clin Gastroenterol 32 (4):340-343

8. Felig DM, Brusilow SW, Boyer JL (1995) Hyperammonemic coma due to parenteral nutrition in a woman with heterozygous ornithine transcarbamylase deficiency. Gastroenterology 109 (1):282-284

9. Summar ML, Barr F, Dawling S, Smith W, Lee B, Singh RH, Rhead WJ, Sniderman King L, Christman BW (2005) Unmasked adult-onset urea cycle disorders in the critical care setting. Crit Care Clin 21 (4 Suppl):S1-8

10. Tuchman M, Morizono H, Rajagopal BS, Plante RJ, Allewell NM (1998) The biochemical and molecular spectrum of ornithine transcarbamylase deficiency. $J$ Inherit Metab Dis. 21 (Suppl 1):40-58 


\section{Figure legend}

Fig. 1 Correlation of hyperammonemia and encephalopathy with corticosteroid administration. A, Cumulative cortisol-equivalent dose. Vertical dotted lines point to onsets and offsets of corticosteroid administration. Cortisol equivalent doses were calculated assuming: $30 \mathrm{mg}$ cortisol i.v $=7.5 \mathrm{mg}$ prednisolone i.v. $=6 \mathrm{mg}$ methylprednisolone p.o. $=1 \mathrm{mg}$ dexamethasone i.v./p.o. $\boldsymbol{B}$, Time course of plasma ammonia in relation to episodes of encephalopathy (vertical grey bars). Reference range is indicated by horizontal dashed lines. Note that high cumulative doses of corticosteroids (>7 g cortisol equivalent) apparently triggered hyperammonemic encephalopathy, whereas lower doses did not 


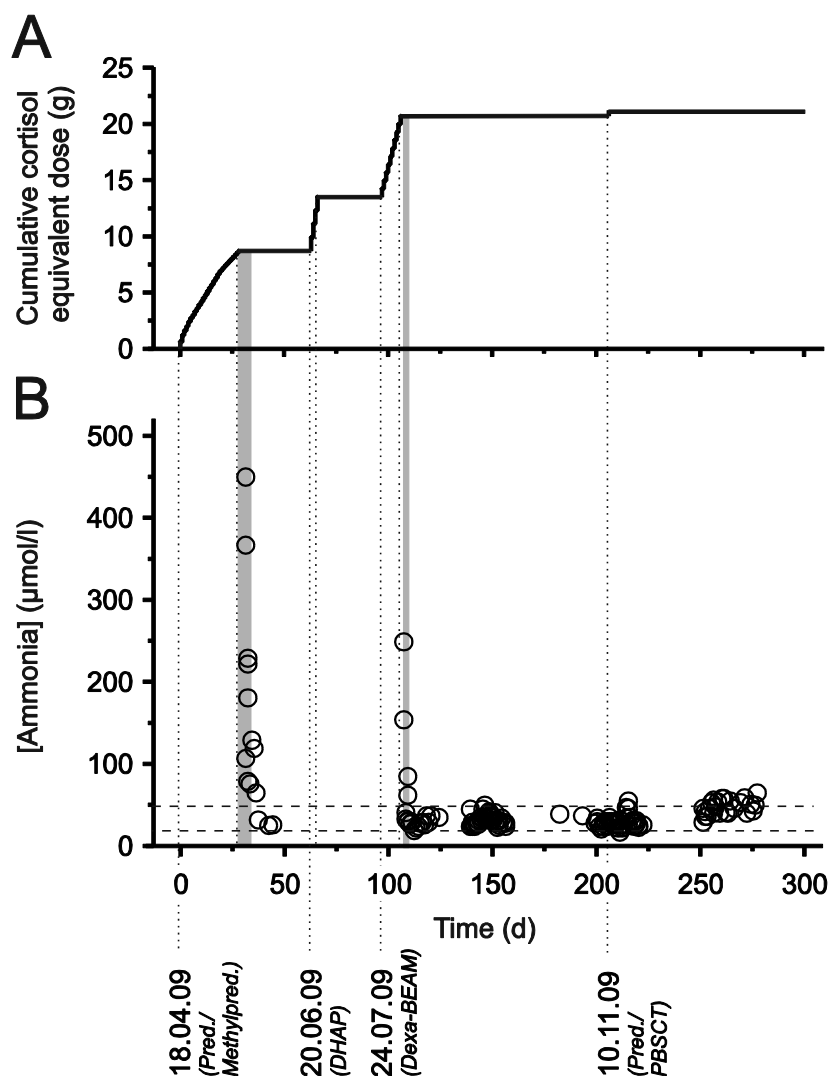

